\title{
Mengembangkan Kreativitas Aptitude Anak dengan Strategi Habituasi dalam Keluarga
}

\author{
Dwi Okti Sudarti ${ }^{1}$ \\ ${ }^{1}$ Jurusan Interdisciplinary Islamic Studies, Fakultas Pascasarjana, Universitas Islam Negeri Sunan Kalijaga, \\ Jalan Marsda Adisucipto, Papringan, Caturtunggal, Sleman Yogyakarta 55281 \\ Penulis Untuk Korespondensi/Email: Dwiokti11@gmail.com
}

\begin{abstract}
Abstrak - Kreativitas merupakan salah satu soft skill penting yang harus dimiliki setiap insan. Kreativitas ialah interaksi antara kekuatan intelektif, emotif, dan motivasional. Oleh karenanya, mengembangkan kreativitas anak sangat penting untuk membantu perkembangan kreativitasnya mencakup aspek kognitif, sosial, emosional, dan afektif. Artikel ini akan membahas kreativitas aptitude anak usia dini 4-6 tahun. Anak usia dini sering disebut "golden age" atau masa emas. Pada masa ini hampir semua potensi anak mengalami masa peka untuk tumbuh berkembang. Dalam menumbuh kembangkan kreativitas dimulai dari lingkup terkecil yaitu keluarga. Lingkungan keluarga merupakan salah satu dari tri pusat pendidikan yang bersinergi memberikan pendidikan bagi anak. Penelitian ini bertujuan untuk mengetahui bagaimana mengembangkan kreativitas aptitude anak dengan strategi habituasi dalam lingkungan keluarga, serta bagaimana peran orang tua dalam mengembangkan kreativitas anak. Metode yang digunakan dalam penelitian ini ialah deskriptif kualitatif dengan pendekatan studi pustaka. Penelitian ini memanfaatkan berbagai referensi berupa buku-buku dan jurnal-jurnal yang memiliki kaitan dengan tema yang dibahas untuk mengolah dan menganalisis data. Hasil penelitian menunjukkan bahwa kreativitas aptitude anak dapat dikembangkan melalui strategi habituasi. Pembiasaan dan pembudayaan adalah sifat dalam pikiran. Jika strategi habituasi terus diulang dan dibudayakan dalam keluarga untuk mengembangkan kreativitas aptitude anak. Maka, akan menjadi karakter yang dapat melekat dalam jiwa anak.
\end{abstract}

Abstract - Creativity is one of the important soft skills that every human being must possess. Creativity is the interaction between intellectual, emotive, and motivational forces. Therefore, developing children's creativity is very important to assist the development of creativity including cognitive, social, emotional, and affective aspects. This article will discuss the aptitude of 4-6 years of early childhood aptitude creativity. Early childhood is often called the "golden age" or golden age. At this time almost all the potential of children experiencing sensitive periods to grow and develop. In developing creativity starts from the smallest scope, namely the family. The family environment is one of the tri education centers that work together to provide education for children. This study aims to find out how to develop children's aptitude creativity with habituation strategies in the family environment, as well as how the role of parents in developing children's creativity. The method used in this research is a descriptive qualitative approach to literature study. This research utilizes various references in the form of books and journals related to the themes discussed to process and analyze data. The results showed that children's aptitude creativity can be developed through habituation strategies. Habituation and civilizing are traits in mind If the habituation strategy continues to be repeated and cultivated in the family to develop children's aptitude creativity. Then, it will become a character that can be inherent in a child's soul.

Keywords - Aptitude Creativity, Habituation Strategy, Family Environment

PENDAHULUAN

$\mathrm{D}$ alam kehidupan sehari-hari manusia tidak bisa lepas dari kreativitas. Kreativitas dipandang sangat berarti dalam proses kehidupan manusia. Kreatif sendiri memiliki beberapa norma. Norma yang pertama adalah gradasi, norma ini berhubungan dengan kapasitas dan abilitas yang 
dimiliki masing - masing individu. Kedua adalah norma level/tahapan, yaitu norma yang berhubungan dengan tingkatan mutu kreativitas yang dicapai oleh individu pada titik tertentu dalam perjalanan usianya. Ketiga, norma periode yaitu norma yang berhubungan dengan apa yang dicapai individu pada titik tertentu dalam sejarah/kebudayaan manusia, dan keempat adalah norma degree atau taraf, yaitu manifestasi dari tiga norma sebelumnya (gradasi, level, dan periode) yang disejawantahkan dengan kreativitas itu sendiri [1].

Kreativitas merupakan kemampuan yang dimiliki seseorang untuk menemukan dan menciptakan hal baru, cara-cara baru, gagasan-gagasan baru yang berguna bagi dirinya dan masyarakat. Hal baru tidak perlu sesuatu yang belum ada sebelumnya, tetapi unsur-unsurnya mungkin sudah ada sebelumnya tetapi individu menemukan kombinasi baru, hubungan baru, konstruk baru yang memiliki kualitas yang berbeda dengan keadaanya sebelumnya, hal baru ini sifatnya bersifat inovatif. Kreativitas didasari oleh segi-segi intelektual, seperti kecerdasan, bakat dan kecakapan nyata, juga segi efektif seperti sikap, minat dan motivasi. Contohnya seorang ibu rumah tangga merangkap sebagai wanita karir selalu dihadapkan dengan berbagai kegiatan baik didalam maupun diluar rumah contohnya dalam mengurus rumah tangga seperti anak, suami, kemudian harus mengurus pekerjaannya sendiri sebagai wanita karir. Hal yang demikian itu dibutuhkan kreativitas yang tinggi untuk dapat memanajemen waktu dengan baik antara pekerjaan serta kewajiban sebagai wanita untuk mengurus rumah tangga supaya keduanya bisa dijalankan beriringan tidak terabaikan.

Beberapa ahli mengemukakan beberapa makna kreativitas, menurut David Campbell kreativitas adalah suatu kemampuan untuk menciptakan hasil yang sifatnya baru, inovatif, belum ada sebelumnya, menarik, aneh, dan berguna bagi masyarakat [2].

Menurut Munandar dalam konsep kreativitas ciriciri seseorang juga dapat dilihat dari sisi dalam manusia, yang dibagi menjadi 2, yaitu ciri aptitude ialah ciri-ciri yang berhubungan dengan kognisi dan proses berpikir. Sedangkan ciri nonaptitude ialah ciri-ciri yang berkaitan dengan sikap atau perasaan. Kedua jenis ciri kreativitas itu diperlukan agar perilaku kreatif dapat terwujud. Berikut ini adalah uraian dari ciri-ciri aptitude dan nonaptitude [3]. Dalam tulisan ini penulis akan membahas mengenai kreativitas aptitude yang berhubungan dengan kognisi dan proses berpikir pada anak usia dini.

Berdasarkan kajian neurologi, ketika anak dilahirkan, otak bayi mengandung 100 milyar neuron yang siap melakukan sambungan antar sel selama tahun-tahun pertama. Otak bayi akan berkembang sangat pesat dengan menghasilkan bertrilyun sambungan antar neuron. Sambungan yang bertrilyun tersebut harus diperkuat melalui rangsangan psikososial. Karena bila tidak diperkuat dengan rangsangan psikososial akan mengalami antrofi (penyusutan) dan musnah sehingga mepengaruhi tingkat kecerdasan anak [4]. Dalam kajian lain diungkapkan bahwa sekitar 50\% kapasitas kecerdasan manusia terjadi ketika anak berumur 4 tahun. $80 \%$ terjadi ketika berumur 8 tahun [5]. Maka dari itu pada masa ini anak usia dini disebut sebagai masa emas.

Anak usia dini merupakan masa yang sangat potensial dalam mengembangkan potensi yang dimiliki oleh anak. Potensi itu akan berkembang apabila mendapat stimulasi atau rangsangan yang baik dari luar dirinya melalui rangsangan yang diberikan, rangsangan ini berupa strategi pembiasaan.

Kebiasaan dan pembudayaan adalah yang memberikan sifat dan jalan tertentu dalam pikiran [6]. Kebiasaan akan menjadi katakter jika seseorang senang kepada sesuatu yang dibiasakan dan diterimanya. Maka dari itu jika anak mulai dibiasakan untuk berpikir kreatif sejak usia dini maka pembiasaan ini akan membekas sampai anak dewasa [7].

Menurut [8] kreativitas perlu dikembangkan sejak kecil dalam lingkungan keluarga karena kehidupan pertama anak dalam lingkungan keluarga cenderung bertahan dan mempengaruhi sikap serta perilaku anak sepanjang hidupnya Pembiasaan itu bisa terwujud apabila anak mendapatkan pendidikan dalam lingkup terkecil terlebih dahulu yaitu keluarga.

Keluarga merupakan wadah pertama dan dasar yang fundamental bagi perkembangan dan pertumbuhan anak. Disinilah pertama kali anak mengenal norma sosial, belajar memperhatikan keinginan orang lain, interaksi sosial di keluarga, pengalaman dalam interaksi sosial dikeluarga turut menentukan cara bertindak dan bereaksi pergaulan sosial yang lebih besar seperti masyarakat [9]. Rodi 
dan Salovey yang dikutip oleh Utami mengungkapkan bahwa keluarga adalah sumber dukungan sosial yang paling penting bagi perkembangan anak dan mendorong individu berkembang kreativitasnya [10]. Sikap orang tua dalam memberikan pendidikan merupakan faktor penentu yang positif dari kinerja kreatif seorang anak .

Lingkungan keluarga yang baik adalah lingkungan dimana orang tua memberikan lebih banyak kesempatan dan kebebasan pada anak untuk memahami dan bertindak sesuai dengan keinginan anak dengan tidak lepas dari pengawasan dan arahan orang tua. Lingkungan yang kaya stimulasi dalam keluarga sangat penting untuk setiap anak sehingga anak menjadi lebih optimis dalam membangun kecerdasan sosial dan kognitifnya. Menurut Hurlock iklim dan suasana rumah dalam lingkungan keluarga dipengaruhi oleh afeksi, respon kerjasama, dan toleransi antar anggota keluarga. Anak yang tinggal dalam keluarga yang mendukung dan terorganisir akan mengalami peningkatan kepercayaan diri, memiliki kompetensi sosial, lebih mandiri dan mampu menyelesaikan masalah dengan berbagai cara sehingga anak tidak mengalami penurunan kecemasan [11].

Adapun tujuan dari artikel ini ialah untuk mengetahui bagaimana lingkungan keluarga mengembangkan kreativitas aptitude anak dengan strategi habituasi. Berdasarkan tujuan tersebut maka muncul lah rumusan masalah. Rumusan masalah dalam artikel ini ialah, bagaimana mengembangkan kreativitas anak dengan menggunakan strategi habituasi. Metode dalam artikel ini menggunakan metode kajian pustaka.

\section{METODE}

Metode yang digunakan dalam penelitian ini ialah deskriptif kualitatif, dengan pendekatan studi pustaka (library research). Penelitian ini memanfaatkan berbagai referensi berupa bukubuku dan jurnal-jurnal yang memiliki kaitan dengan tema yang dibahas untuk mengolah dan menganalisis data. Tujuannya untuk mengetahui bagaimana mengembangkan kreativitas aptitude anak menggunakan strategi habituasi (pembiasaan) dalam keluarga, serta menyajikan bagaimana peran orangtua dalam mengembangkan kreativitas anak.

\section{HASIL DAN PEMBAHASAN}

\section{Pengertian Kreativitas}

Kreativitas merupakan kemampuan yang dimiliki seseorang untuk menemukan dan menciptakan hal baru, cara-cara baru, gagasan-gagasan baru yang berguna bagi dirinya dan masyarakat. Hal baru tidak perlu sesuatu yang belum ada sebelumnya, tetapi unsur-unsurnya mungkin sudah ada sebelumnya tetapi individu menemukan kombinasi baru, hubungan baru, konstruk baru yang memiliki kualitas yang berbeda dengan keadaanya sebelumnya, hal baru ini sifatnya bersifat inovatif Menurut Utami Munandar kreativitas adalah kemampuan (1) Membuat kombinasi baru berdasarkan data, informasi atau unsur yang ada, (2) Berdasarkan data atau informasi yang tersedia, menemukan kemungkinan jawaban terhadap suatu masalah yang penekanannya pada kualitas dan (3) Mencerminkan kelancaran, orisinilitas dalam berfikir serta kemampuan untuk mengelaborasi suatu gagasan.

Guilford mengemukakan bahwa ada lima sifat yang menjadi ciri-ciri kemampuan berfikir kreatif yakni (1) Lancar (fluency) yaitu kemampuan untuk menghasilkan banyak gagasan, (2) Keluwesan (flexibility) yaitu kemampuan untuk mengemukakan bermacam-macam pemecahan atau pendekatan masalah, (3) Keaslian (originality) yaitu kemampuan untuk memecahkan gagasan dengan cara-cara yang asli. Tidak plagiasi, murni dari pemikirannya sendiri (4) Penguraian (elaboration) yaitu kemampuan untuk menguraikan sesuatu dengan rinci secara jelas dan panjang lebar. Jadi siswa ketika ditanya atau menjelaskan mampu menyebutkan secara mendetail. [12].

Perumusan kembali (redefinition) yaitu kemampuan untuk peninjauan suatu persoalan berdasarkan persepektif yang berbeda dengan apa yang telah diketahui oleh banyak orang [13]. Jadi siswa mampu menyampaikan kembali persoalan yang sudah dibahas dan mempunyai pandangan berbeda untuk suatu pemecahan.

Dalam konsep kreativitas, ciri-ciri seseorang juga dapat dilihat dari sisi dalam manusia, yang dibagi menjadi 2, yaitu ciri aptitude ialah ciri-ciri yang berhubungan dengan kognisi dan proses berpikir. Sedangkan ciri nonaptitude ialah ciri-ciri yang berkaitan dengan sikap atau perasaan. Kedua jenis ciri kreativitas itu diperlukan agar perilaku kreatif dapat terwujud. Berikut ini adalah uraian dari ciriciri aptitude dan nonaptitude [10]: 


\section{Ciri-Ciri Berpikir Kreatif (Aptitude)}

Ketrampilan berpikir lancar

Mencetuskan banyak gagasan, pertanyaan, jawaban, penyelesaian masalah, saran, dan pendapat untuk melakukan berbagai hal. Contohnya: mengajukan banyak pertanyaan, lancar mengungkapkan gagasannya, dan dapat dengan cepat melihat kesalahan atau kekurangan pada suatu obyek/situasi.

Ketrampilan berpikir luwes (fleksibel)

Melihat suatu permasalahan dari berbagai sudut pandang, mampu mencari banyak alternatif atau solusi suatu hal. Contohnya: mampu mengubah arah berpikir secara spontan, mampu memikirkan macam-macam cara penyelesaian masalah, slalu mempunyai pandangan yang berbeda dengan mayoritas kelompok.

\section{Ketrampilan berpikir orisinal}

Mampu melahirkan ungkapan yang baru dan unik, mampu mengkombinasikan sesuatu dengan tidak lazim. Contohnya : memikirkan masalah yang tidak pernah terpikirkan oleh orang lain.

\section{Ketrampilan memperinci (mengelaborasi)}

Mampu menambahkan atau memperinci secara detail dari suatu obyek, gagasan atau situasi. Contohnya : mencoba menguji detail-detail suatu hal untuk melihat arah yang akan ditempuh.

Ketrampilan menilai (mengevaluasi) Mengambil keputusan terhadap situasi , tidak hanya mencetuskan pendapat namun juga melaksanakannya. Contohnya: menganalisis masalah secara kritis dengan selalu menanyakan "Mengapa", merancang rencana yang akan dilakukan [10].

\section{Ciri-Ciri Bersikap Kreatif (Nonaptitude)}

Rasa ingin tahu

Selalu terdorong ingin mengetahui lebih banyak, peka terhadap sesuatu. Contohnya: mempertanyakan segala sesuatu.

\section{Bersifat imajinatif}

Mampu memperkirakan hal-hal yang belum pernah terjadi. Contohnya: meramalkan apa yang dilakukan/dikatakan orang lain.

\section{Merasa tertantang oleh kemajemukan}

Terdorong mengatasi masalah yang sulit, tertantang dengan situasi yang rumit. Contohnya: tidak cenderung memilih jalan yang gampang atau sudah biasa, berusaha terus menerus agar berhasil.

\section{Sifat berani mengambil resiko}

Tidak takut gagal, tidak ragu-ragu dalam mengambil keputusan. Contohnya: berani menjawab pertanyaan meski belum tentu benar.

\section{$\underline{\text { Sifat menghargai }}$}

Contohnya: menghargai diri sendiri dan orang lain [10].

\section{Tahap perkembangan kognitif anak}

Istilah kognitif padanannya knowing yang berarti mengetahui [14]. Pada aspek pengembangan kognitif, kompetensi dan hasil belajar yang diharapkan pada anak adalah anak mampu dan memiliki kemampuan berfikir secara logis, berfikir kritis, dapat memeberi alasan, mampu memecahkan masalah dan menemukan hubungan sebab akibat dalam memecahkan masalah yang dihadapi [15].

Piaget meyakini bahwa anak merupakan pembangun kecerdasan yang aktif lewat asimilasi (penerimaan pengalaman baru) dan akomodasi (mengubah skema yang sudah ada untuk disesuaikan dengan informasi baru), yang menghasilkan keseimbangan [16].

Khusus pada anak usia dini, Piaget menyatakan bahwa pengetahuan dapat diperoleh melalui eksplorasi, manipulasi, dan konstruksi secara elaboratif. Lebih dari itu, Piaget juga menjelaskan bahwa karakterisasi aktivitas anak-anak juga berdasarkan pada tendensi-tendensi biologis yang terdapat pada semua organisme. Tendensi-tendensi tersebut mencakup tiga hal, yaitu asimilasi, akomodasi, dan organisasi [17].

Pertama, asimilasi. Secara harfiah, asimilasi berarti memasukkan atau menerima. Dalam lingkup pengetahuan, manusia selalu mengasimilasikan objek atau informasi ke dalam struktur kognitifnya. Pada awalnya, seorang bayi mencoba berasimilasi dengan menyentuh, meremas, bahkan merobek benda-benda yang dijangkaunya. Selanjutnya, anak akan mengasimilasi objek tersebut dengan memasukkannya ke dalam mulut sebagai ekspresi rasa ingin tahu.

Kedua akomodasi. Akomodasi adalah mengubah struktur diri. Dalam melihat beberapa objek, belum tentu anak mempunyai struktur penglihatan (diri) yang memadai, sehingga anak tersebut harus melakukan akomodasi. Misalnya, seorang anak 
dapat memindahkan balok terbesar mainannya hanya dengan menggeser rintangan di depannya. Nah, kemampuan menggeser rintangan untuk memindahkan balok itulah disebut akomodasi.

Ketiga, organisasi. Yang dimaksud organisasi di sini adalah menggabungkan ide-ide tentang sesuatu ke dalam sistem berpikir yang koheren (masuk akal). Hal ini hanya bisa dilakukan dengan menggabungkan asimilasi dan akomodasi, sebagaimana disebutkan di atas. Sekedar contoh, anak-anak pada usia 5-6 tahun telah terampil mengendarai roda tiga. Dalam kemampuannya itu, anak telah mampu merangkai beberapa ide, seperti kaki mangayuh pedal, tangan memegang setir, mata menatap ke depan, dan sering kali kepala anak tersebut menoleh ke kanan dan ke kiri untuk menjaga keselamatan. Inilah yang disebut dengan organisasi dalam bahasa tendensi biologis [18].

Perkembangan kognitif adalah perkembangan kemampuan anak untuk mengeksplorasi lingkungan karena bertambah besarnya koordinasi dan pengendalian motorik, maka dunia kognitif anak berkembang pesat, makin kreatif, bebas dan imajinatif [19]. Pikiran anak mulai aktif sejak lahir, dari hari ke hari sepanjang pertumbuhannya. Perkembangan pikirannya, seperti: belajar tentang orang, belajar tentang sesuatu, belajar tentang kemampuan-kemampuan baru, memperoleh banyak ingatan, menambah banyak pengalaman. Sepanjang perkembangannya pikiran anak, maka anak akan menjadi lebih cerdas [20].

Sebagai orang tua yang menjadi pendidikan pertama bagi anak, harus mampu membekali dan mengajari anak kemampuan untuk mengembangkan kreativitasnya melalui pembiasaan yang telah diterapkan dari anak kecil agar anak mengetahui dan memahami lingkungan sekitarnya melalui panca indra yang anak miliki, sehingga seiring berjalannya waktu mereka mampu memiliki kemampuan berfikir secara logis dan dapat memecahkan masalah yang dihadapi kemudian dapat menjadi bekal setelah anak tumbuh dewasa. Maka dari itu peran orang tua harus dapat mengembangkan kreativitas anak, dalam penelitian ini berhubungan dengan kreativitas aptitude anak dengan menggunakan strategi pembiasaan.

Perkembangan kognitif menggambarkan bagaimana pikiran anak berkembang dan berfungsi sehingga dapat berpikir dengan cara-cara yang unik. Semua anak memiliki pola perkembangan kognitif yang sama, yaitu meliputi empat tahapan adalah:

1. Pertama, Tahap Sensori Motorik (0-2 tahun). Disebut Sensori Motorik karena pembelajaran anak hanya melibatkan panca indra. Anak belajar untuk mengetahui dunianya hanya mengandalkan indera yaitu melalui mengisap, menangis, menelan, meraba, membau, melihat, mendengar, dan merasakan. Dalam teori Piaget, dua proses, adaptasi (adaptation) adalah melibatkan pengembangan skema melalui interaksi langsung dengan lingkungan. Dan organisasi (organization) adalah sebuah proses yang terjadi secara internal, terpisah dari kontak langsung dengan lingkungan. Setelah anak-anak membentuk skema baru, mereka mengaturnya kembali, menghubungkannya dengan skema lain untuk menciptakan sebuah sistem kognitif yang saling berhubungan erat yang berperan dalam perubahan skema [21].

\section{Tahap Praoperasional (2-7 tahun)}

Tahap Praoperasional (early childhood) yang membentang selama usia 2 hingga 7 tahun, perubahan paling jelas yang terjadi adalah peningkatan luar biasa dalam aktivitas representasi atau simbolis [21]. Pada tahap ini konsep yang stabil dibentuk, penalaran muncul, egosentris mulai kuat dan kemudian mulai melemah.

Ciri-ciri tahap pra-operasional adalah (1) anak mengembangkan kemampuan menggunakan simbol, termasuk bahasa; (2) anak belum mampu melakukan pemikiran operasinal (operasi adalah pemikiran yang dapat dibalik), yang menjelaskan mengapa Piaget menamai tahap ini praoperasional; (3) anak terpusat pada satu pemikiran atau gagasan, seringkali di luar pemikiran-pemikiran lainnya; (4) anak belum mampu menyimpan ingatan; dan (5) dan bersifat egosentris [16].

Pemikiran praoperasional dapat dibagi menjadi sub-sub tahapan, yaitu:

a. Sub Tahapan Fungsi Simbolik adalah sub tahapan pertama dari pemikiran praoperasional, yang terjadi kira-kira antar usia 2 hingga 4 tahun. Kemampuan ini sangat memperluas dunia mental anak. Kemajuan pemikiran mereka masih memiliki beberapa batasan-batasan yang penting, dua diantaranya adalah egosentrisme dan animisme.

b. Sub Tahapan Pemikiran Intuitif Sub tahapan pemikiran intuitif adalah sub tahapan kedua dari pemikiran praoperasional, terjadi kira-kira antara 
usia 4 hingga 7 tahun. Dalam sub tahapan ini, anakanak mulai menggunakan pemikiran primitif dan ingin tahu jawaban dari semua pertanyaan. Piaget menyebut sub tahapan ini karena anak-anak tampaknya sangat yakin dengan pengetahuan dan pemahaman mereka, tetapi tidak sadar bagaimana mereka mengetahui apa yang mereka ketahui.

3 Tahap Operasional Konkret (7-11 tahun).

Tahap ini membentang dari usia 7 hingga 11 tahun dan menandai suatu titik-balik besar dalam perkembangan kognitif. Pikiran jauh dari sekedar logika. Ia bersifat fleksibel dan lebih teratur dari sebelumnya. Anak-anak di tingkatan operasi operasi berpikir konkret sanggup memahami dua aspek suatu persoalan secara serentak. Di dalam interaksi-interaksi sosialnya, mereka memhami bukan hanya apa yang akan mereka katakan, tapi juga kebutuhan pendengarannya. Selama tahuntahun sekolah, anak-anak menerapkan skemaskema logis untuk lebih banyak tugas. Dalam proses ini, pemikiran mereka tampaknya mengalami perubahan kualitatif menuju suatu pemahaman komprehensif tentang prinsip-prinsip dasar pemikiran logis [21].

4 Keempat, Tahap Operasional Formal (11 tahun ke atas).

Tahapan ini muncul usia 11 hingga 15 tahun adalah tahapan teori Piaget yang keempat dan terakhir. Tahap Operasional Formal sebuah tahap di mana mereka mengembangkan kemampuan berpikir abstrak, sistematis, dan Ilmiah [21].

\section{Strategi habituasi}

Habituasi (pembiasaan) dan pembudayaan yang baik. Hukum pembiasaan melalui enam tahapan yaitu, berfikir, rekaman, pengulangan, penyimpanan, pengulangan, dan kebiasaan. Penjelasan enam tahapan itu sebagai berikut:

Tabel 1. Strategi Habituasi Berfikir

\begin{tabular}{lll}
\hline & Strategi & \multicolumn{1}{c}{ Penjelasan } \\
\hline 1. & Berfikir & Seseorang memikirkan dan \\
& mengetahui nilai-nilai yang \\
& diberikan, lalu memberi \\
& perhatian & dan \\
& berkonsentrasi pada nilai \\
& tersebut. \\
\hline
\end{tabular}

Orang tua memberitahu anak dan mengajak anak untuk sama-sama berfikir akan pentingnya membuang sampah pada tempatnya. Kemudian orang tua menjelaskan lingkungan akan terlihat kotor, jorok dan tempat menjadi tidak sehat jika sampah berserakan. Maka dari itu membuang sampah pada tempatnya sangat penting.

Tabel 2. Strategi Habituasi Rekaman

\begin{tabular}{lll}
\hline \multicolumn{1}{c}{ Strategi } & \multicolumn{2}{c}{ Penjelasan } \\
\hline 2. & Rekaman & Setelah nilai diterima \\
& otaknya merekam. Otaknya \\
& kemudian membuka file \\
& sejenis & dengan \\
& menghubungkannya dengan \\
& pikiran lain yang sejenis \\
& atau yang bermanfaat \\
& baginya. \\
\hline
\end{tabular}

Setelah orang tua mengajak anak untuk berfikir bersama memberi pemahaman dan penjelasan anak akan merekam apa yang dijelaskan orang tua nya, kemudian di satu kesempatan anak melihat ada sampah yang berserakan dirumah anak akan membuangnya ke tempat sampah, sesuai apa yang diajarkan oleh orang tuanya dirumah agar rumah terlihat bersih dan rapi.

Tabel 3. Strategi Habituasi Pengulangan

\begin{tabular}{ll}
\hline Strategi & \multicolumn{2}{c}{ Penjelasan } \\
\hline 3. Pengulangan & Seseorang memutuskan \\
& untuk mengulangi nilai \\
& yang baik itu dengan \\
& perasaan yang sama. \\
\hline
\end{tabular}

Ketika anak sudah mengetahui manfaat membuang sampah pada tempatnya dan mulai terbiasa untuk membuang sampah pada tempatnya. Anak akan selalu melakukan kegiatan tersebut dengan hati yang senang.

Tabel 4. Strategi Habituasi Penyimpanan

\begin{tabular}{llr}
\hline \multicolumn{1}{c}{ Strategi } & \multicolumn{2}{c}{ Penjelasan } \\
\hline 4. Penyimpanan & Karena & perekaman \\
& dilakukan & berkali-kali \\
& terhadap perilaku nilai-nilai \\
& yang masuk pikiran \\
& menjadi semakin kuat. Akal \\
& menyimpannya dalam file \\
& dan hadir setiap kali \\
& manusia & menghadapi \\
& kondisi yang serupa. \\
\hline
\end{tabular}

Ketika anak sudah mulai terbiasa untuk membuang sampah pada tempatnya maka perbuatan tersebut akan melekat pada fikiran anak. Setelah melakat jika dikemudian hari anak menemukan ada sampah di tempat yang tidak seharusnya, maka anak akan dengan spontan mengambil sampah itu dan mencari kotak sampah untuk membuangnya. 
Tabel 5. Strategi Habituasi Pengulangan

\begin{tabular}{clr}
\hline Strategi & \multicolumn{2}{c}{ Penjelasan } \\
\hline 5. Pengulangan & Pengulangan disadari atau \\
& tidak, & seseorang \\
& mengulangi & kembali \\
& perilaku nilai yang baik \\
& yang tersimpan kuat dalam \\
& akal bawah sadarnya. \\
& Setiap kali memori yang \\
& tersimpan diakal bawah \\
& sadar itu diulang, ia \\
& semakin kuat dalam jiwa. \\
\hline
\end{tabular}

Perbuatan yang terus dilakukan dan diulang oleh anak seperti membuang sampah pada tempatnya jika sering dilakukan akan semakin kuat dalam jiwa anak.

Tabel 6. Strategi Habituasi

\begin{tabular}{lll}
\hline & Strategi & \multicolumn{2}{c}{ Penjelasan } \\
\hline 6. & Kebiasaan & Karena pengulangan nilai \\
menjadi & baik yang berkelanjutan \\
karakter & maupun tahapan yang \\
& & sudah dilalui, akal manusia \\
& meyakini bahwa kebiasaan \\
& ini merupakan bagian \\
& terpenting dari perilaku. \\
\hline
\end{tabular}

Ketika nilai tersebut sudah melekat kuat dalam jiwa anak maka kebiasaan membuang sampah pada tempatnya akan menjadi karakter.

Berdasarkan penjelasan mengenai strategi habituasi yang sudah dipaparkan pada tabel. Dapat diambil kesimpulan bahwa jika dari kecil seorang anak sudah di ajarkan oleh orang tua akan pentingnya membuang sampah kemudian dipraktikan oleh anak tersebut karena anak sudah mengerti bahwa merasa sampah itu penting untuk dibuang ditempatnya. Kemudian disuatu waktu anak menemukan sampah tergeletak dan langsung berinisiatif membuangnya lagi pada tempatnya maka jika berulang terus-menerus akan menjadi sebuah karakter. Bahkan bisa jadi jika menemukan sampah yang dibuang sembarangan kemudian tidak ada inisiatif untuk membuangnya, akan merasa seperti ada yang kurang, karena secara naluriah sudah terbiasa membuang sampah pada tempatnya. Ini yang dinamakan proses habituasi atau pembiasaan yang berujung pada pembentukan karakter.

\section{Lingkungan keluarga}

Lingkungan keluarga merupakan salah satu dari tri pusat pendidikan yang bersinergi dalam memberikan pendidikan bagi anak. Keluarga merupakan wadah pertama dan dasar yang fundamental bagi perkembangan dan pertumbuhan anak. Disinilah pertama kali anak mengenal norma sosial, belajar memperhatikan keinginan orang lain, interaksi sosial di keluarga, pengalaman dalam interaksi sosial dikeluarga turut menentukan cara bertindak dan bereaksi pergaulan sosial yang lebih besar seperti masyarakat [9]. Rodi dan Salovey yang dikutip oleh Utami Munandar mengungkapkan bahwa keluarga adalah sumber dukungan sosial yang paling penting bagi perkembangan anak dan mendorong individu berkembang kreativitasnya [22]. Menurut Elizabeth Hurlock kreativitas perlu dikembangkan sejak kecil dalam lingkungan keluarga karena kehidupan pertama anak dalam lingkungan keluarga cenderung bertahan dan mempengaruhi sikap serta perilaku anak sepanjang hidupnya [8].

Pendidikan dalam lingkungan keluarga dapat menjadi efek penyangga yaitu menahan efek-efek negatif dari lingkungan luasnya anak [23]. Sikap orang tua dalam memberikan pendidikan merupakan faktor penentu yang positif dari kinerja kreatif seorang anak [22]. Lingkungan keluarga yang baik adalah lingkungan dimana orang tua memberikan lebih banyak kesempatan dan kebebasan pada anak untuk memahami dan bertindak sesuai dengan keinginan anak dengan tidak lepas dari pengawasan dan arahan orang tua.

Lingkungan yang kaya stimulasi dalam keluarga sangat penting untuk setiap anak sehingga anak menjadi lebih optimis dalam membangun kecerdasan sosial dan kognitifnya. Menurut Hurlock iklim dan suasana rumah dalam lingkungan keluarga dipengaruhi oleh afeksi, respon kerjasama, dan toleransi antar anggota keluarga. Anak yang tinggal dalam keluarga yang mendukung dan terorganisir akan mengalami peningkatan kepercayaan diri, memiliki kompetensi sosial, lebih mandiri dan mampu menyelesaikan masalah dengan berbagai cara sehingga anak mengalami penurunan kecemasan [3].

Lingkungan keluarga merupakan salah satu faktor yang mempengaruhi tingkat kreativitas anak. Sebagian besar, latar belakang pendidikan orang tua dan status ekonomi keluarga berkontribusi terhadap lingkungan rumah yang mereka sediakan untuk anak-anak. Orang tua memiliki pengaruh yang sangat besar pada pendidikan anak-anak untuk beberapa alasan. Alasan pertama bahwa orang tua merupakan guru pertama bagi anak. Alasan kedua 
bahwa orang tua yang memiliki latar belakang pendidikan yang baik yang diberikan oleh orang tuanya dulu akan memiliki waktu yang jauh lebih mudah dalam mendidik anak dibandingkan dengan orang tua yang kurang mendapat didikan orang tua ketika kecilnya. Pendidikan yang diterima anak sangat tergantung pada pendidikan yang orang tua mereka terima ketika mereka masih anak-anak.

Kreativitas sangat penting, maka sejak dini anakanak diperkenalkan dengan dasar-dasar kreativitas. Hal yang dapat dilakukan orang tua kepada anak sejak dini adalah sebagai berikut [24]:

Tabel 7. Ciri-Ciri Kreativitas Dalam Keluarga

\begin{tabular}{cll}
\hline \multicolumn{2}{c}{ Ciri-Ciri Kreativitas } & \multicolumn{2}{c}{ Penjelasan } \\
\hline 1. & Menunjang dan & Orangtua yang bijak \\
mendorong & dan peduli akan \\
kegiatan yang & kreativitas anak akan \\
diminati anak. & senatiasa menunjang \\
& dan mendorong setiap \\
& kegiatan positif anak. \\
\hline
\end{tabular}

Anak bisa dimintai penjelasannya mengenai minat dan harapannya ketika menginjak dewasa kelak. Misalnya dengan cara menanyakan, ingin jadi apa? Setelah diketahui bahwa anak ingin menjadi seorang polisi atau pelukis, maka sejak dini orang tua dapat memperkenalkan berbagai hal yang berkenaan dengan dunia kepolisian atau seni keindahan dari lukisan. Paling tidak, orang tua sudah memberikan rangsangan khayal anak sehingga ia memiliki rencana-rencana tersendiri dengan cita-citanya itu.

Tabel 8. Ciri-Ciri Kreativitas Dalam Keluarga

\begin{tabular}{ccl}
\hline \multicolumn{2}{c}{ Ciri-Ciri Kreativitas } & \multicolumn{2}{c}{ Penjelasan } \\
\hline 2. & Mendorong & Alangkah baiknya jika \\
kemandirian anak & dalam memberikan \\
dalam bekerja & bantuan kepada anak \\
& tidak serta-merta \\
& segala kebutuhan anak \\
& secepatnya dipenuhi. \\
\hline
\end{tabular}

Perbuatan yang demikian itu akan mengakibatkan anak makin manja dan malas bekerja. Manakala anak meminta bantuan orang tua dalam mewarnai, sang ayah mestinya terlebih dahulu memberikan motivasi, sehingga ia merasa mampu meyelesaikan kegiatan yang dihadapinya. Sang ayah dapat berkata demikian: " Wah...bagus benar gambarnya, kalau bukan Ade yang mewarnai pasti tidak sebagus ini. Pasti tidak akan selesai seperti Ade ya...? Coba sekarang Ade mewarnai rumahnya dulu, nanti ayah yang mewarnai pohonnya..."
Tabel 9. Ciri-Ciri Kreativitas Dalam Keluarga

\begin{tabular}{lll}
\hline \multicolumn{2}{c}{ Ciri-Ciri Kreativitas } & \multicolumn{2}{c}{ Penjelasan } \\
\hline 3. & Memberi & Orangtua tidak harus \\
kesempatan & selalu memaksakan \\
kepada anak & kehendaknya untuk anak \\
untuk berpikir, & ,alngkah baiknya orang \\
merenung & tua memberikan \\
berkhayal. & kesempatan bagi anak \\
& untuk berfikir mandiri,. \\
\hline
\end{tabular}

Jika anak terlalu dipaksa dengan berbagai kegiatan, misalnya dari mulai bangun sampai bangun lagi, selalu dipenuhi agenda tugas yang harus dikerjakan. Jangan heran jika anak nanti akan mudah frustasi. Sebab belum apa-apa saja sudah didikte dengan berbagai kegiatan yang harus diselesaikannya.

Elizabeth Hurlock, pernah mencontohkan dengan aktivitas menyapu. Jika sapu itu dipegang orang dewasa, maka sampah yang berserakan akan bersih dan dapat memberikan kenyamanan. Tapi, jika sapu itu depegang anak-anak, maka bisa jadi sapu itu akan manjadi alat permainan yang mengasyikan baginya. Ia akan mengidentifikasi dirinya sedang "naik kuda", sapu yang dipegangnya menjadi seekor kuda, dan lain sebagainya. Jika anak diperintahkan untuk menyapu oleh orang tua, maka cara menyapunya pun semaunya ekspresi anak. Akibatnya, jika tidak diawasi pekerjaan itu malah tidak akan selesai.

Oleh karena itu, dalam memberikan kegiatan kepada anak, sebaiknya Pembelajaran disesuaikan dengan tingkat perkembangan anak, baik usia maupun dengan kebutuhan individual anak [25].

Tabel 10. Ciri-Ciri Kreativitas Dalam Keluarga

\begin{tabular}{lllr}
\hline \multicolumn{2}{c}{ Ciri-Ciri Kreativitas } & \multicolumn{2}{c}{ Penjelasan } \\
\hline 4. & Merangsang daya & Diskusi merupakan \\
pikir anak dengan & jalan pendalaman \\
cara mengajak & mengenai berbagai \\
berdiskusi tentang & hal, dengan cara \\
hal yang mampu & memeriksa atau \\
dipikirkan anak. & menyelediki sesuatu. \\
\hline
\end{tabular}

Dalam hal ini, orang tua dapat memancing pendapat anak dengan seolah-olah tidak tahu mengenai sesuatu yang sedang dibicarakan. Misalnya, ibu bertanya kepada Dewi: "Dewi, kenapa sih bunga-bunga itu harus disiram?". Tentunya, Dewi akan menjawab sesuai dengan pengetahuan dan pengalaman yang dimilikinya. Bisa jadi Dewi akan menjawab: "Karena kekeringan" Atau, mungkin ia akan mejawab: 
"karena kehausan", atau juga jawaban yang lainnya.

Anak yang terbiasa diajak berdiskusi akan terbentuk menjadi anak percaya diri, mampu mengeluarkan pendapat, rasional, dan teliti. Oleh karena itu, ada baiknya orang tua merangsang anak untuk aktif berdiskusi dengan bertanya tentang apa saja yang sesuai dengan daya pikir anak. Dilakukan bisa sambil bercanda, atau memancing pendapat anak dengan mempertanyakan kembali jawaban yang telah diberikan anak. Misalnya dengan bertanya: "Apa iya?...atau "Ah, yang benar?...", dan sebagainya.

Tabel 11. Ciri-Ciri Kreativitas Dalam Keluarga

\begin{tabular}{lllr}
\hline \multicolumn{2}{c}{ Ciri-Ciri Kreativitas } & \multicolumn{2}{c}{ Penjelasan } \\
\hline 5. & Memberikan & \multicolumn{2}{c}{ Jangan dianggap anak } \\
kesempatan & itu tidak & memiliki \\
kepada anak untuk & keinginan. & Setiap \\
dapat menentukan & individu & memiliki \\
atau mengambil & keinginan menurut \\
keputusan. & kebutuhan dirinya. \\
\hline
\end{tabular}

Tatkala anak menghendaki sesuatu yang menurutnya "penting", maka ada baiknya orang tua menyediakan atau memfasilitasinya. Ketika ingin memilih baju, ada baiknya anak diberikan pilihan dulu ingin warna biru atau merah?. Jika anak mengehendaki yang berwarna biru, itulah keputusan yang dipilih anak.

Ketika anak menentukan pilihan dan memutuskannya, itu berarti bahwa anak memiliki kemampuan untuk mengambil keputusan, meskipun orang tua kurang menyetujuinya. Untuk itu, hargailah apa yang telah dipilih dan diputuskan anak.

Potensi kreatif yang dimiliki manusia hendaknya dipupuk sejak dini oleh orangtua. Pada masa anak usia dini, individu memiliki peluang yang sangat besar untuk dapat mengembangkan potensinya tersebut. Oleh karena itu, daya cipta harus ada dalam pengembangan bahasa, daya pikir, keterampilan, dan jasmani.

Pengembangan kreativitas terlihat dalam pola pikir, daya imajinasi, fantasi (pengandaian) dan hasil karyanya. Menurut Munandar strategi yang dapat digunakan dalam mengembangkan kreativitas adalah dengan menggunakan konsep 4P: pribadi, pendorong, proses, dan produk. Dalam mengembangkan kreativitas anak, orangtua perlu meninjau empat aspek dari kreativitas tersebut [11].
1. Pribadi

Orangtua hendaknya menghargai keunikan dari pribadi kreatif dan bakat-bakat anaknya. Mereka menerima apa adanya karakteristik anak sebagai pribadi kreatif, baik itu karakteristik positif maupun yang menyulitkan. Orangtua hendaknya menghargai karakteristik unik anak dan tidak berusaha membandingkan dengan anak lain. Pada beberapa karakteristik yang menyulitkan seperti tidak kooperatif, egosentris, terlalu asertif, kurang sopan, acuh tak acuh terhadap aturan, keras kepala, emosional, dan menolak dominasi atau otoritas guru, dalam beberapa kasus membutuhkan koreksi dan pengarahan dari orangtua.

\section{Proses}

Memberi kesempatan kepada anak untuk bersibuk diri secara kreatif. Anak diberi kebebasan untuk mengekspresikan diri secara kreatif tanpa merugikan diri sendiri, orang lain ataupun lingkungan. Di samping itu, orangtua harus pula menyediakan sarana dan prasarana yang diperlukan oleh anak untuk menunjang kegiatan kreatifnya. Hal yang harus diingat adalah orangtua tidak boleh terlalu cepat menuntut anak untuk menghasilkan produk-produk kreatif, biarkan anak berproses dengan sendirinya.

\section{Pendorong}

Kreativitas akan berkembang apabila mendapat dorongan dan dukungan dari lingkungannya ataupun ketika terdapat motivasi internal untuk menghasilkan sesuatu. Untuk menumbuhkan motivasi internal orangtua dapat berperan sebagai model bagi anak. Sedangkan dalam mengupayakan lingkungan untuk mendukung kreativitas anak, orangtua perlu memberikan kepercayaan kepada anak bahwa pada dasarnya ia adalah anak baik dan mampu. Orangtua mengusahakan suasana yang didalamnya tidak ada efek mengancam. Orangtua mengenal dan ikut menghayati perasaan, pemikiran, tindakan anak-anak serta memberi kesempatan kepada anak untuk bebas mengekspresikan secara simbolis pikiran-pikiran atau perasaan-perasaannya.

\section{Produk}

Orangtua hendaknya menghargai produk kreatif anak, bila perlu menunjukkan produk kreatif tersebut kepada orang lain. Hal ini akan meningkatkan motivasi anak untuk melakukan kegiatan kreatif.

Pengembangan kreativitas pada anak melalui kegiatan hasil karya ini memiliki posisi penting 
dalam berbagai aspek perkembangan anak. Tidak hanya kreativitas yang akan berpartisipasi untuk berkembang dengan baik, tetapi juga kemampuan kognitif anak. Dalam proses pembuatan suatu karya setiap anak akan menggunakan imajinasinya untuk membentuk sesuatu bangunan atau benda tersebut sesuai dengan khayalannya. Setiap anak bebas menghasilkan mengekspresikan kreativitasnya, sehingga kita akan memperoleh hasil yang berbeda antara satu anak dengan anak lainnya.

\section{KESIMPULAN}

Berdasarkan analisis yang dilakukan dapat disimpulkan bahwa kreativitas aptitude anak dapat dikembangkan melalui strategi habituasi (pembiasaan). Adanya pembiasaan berupa pengajaran yang dilakukan terlebih dahulu oleh orangtua agar anak mengerti dengan apa yang sedang dilakukan dan akan dilakukannya. Kemudian dipraktikan oleh anak, ketika anak sudah mengetahui penting dan tidaknya suatu tindakan tersebut. Maka, anak akan melakukan kegiatan tersebut dengan hati yang senang. Kemudian jika di satu waktu anak kembali di posisi seperti itu, anak sudah bisa mengambil langkah apa yang harus dilakukan, ini berdasarkan dengan pengalaman yang sudah dilalui dan pembiasaan yang sudah diajarkan oleh orangtua kepada anak. Oleh karena itu figur orangtua sangat penting dalam mengajarkan dan memupuk kreativitas sejak dini kepada anak dikarenakan orangtua merupakan pondasi utama dalam keluarga untuk mengenalkan dan mengajarkan nilai-nilai kreativitas kepada anak.

\section{REFERENSI}

[1] P. Tabrani, Kreativitas dan Humanitas: Sebuah Studi Tentang Peranan Kreativitas Dalam Perkehidupan Manusia, Yogyakarta: Jalasutra, 2006.

[2] N. S. Sukmadinata, Landasan Psikologi Proses Pendidikan, Bandung: Remaja Rosdakarya, 2011.

[3] R. H. Moos and B. H. Moos, Family Enviroment Scale Manual, Menlo Park, USA: Mindgarden Inc, 2009.

[4] L. Uce, "The Golden Age: Masa Efektif Merancang Kualitas Anak," Bunayya: Jurnal Pendidikan anak, vol. 1, no. 2, pp. 77-92, 2017.
[5] F. Jalal, "Pendidikan Anak Usia Dini, Pendidikan Yang Mendasar," Buletin Padu, vol. 1, 2002.

[6] Maragustam, Pembentukan Karakter Anak Bangsa, Yogyakarta: Pascasarjana Fakultas Ilmu Tarbiyah dan Keguruan, 2019.

[7] A. Amin, Ethika Ilmu Akhlak, Jakarta: Bulan Bintang, 1975.

[8] E. Hurlock, Perkembangan Anak Jilid 2, Jakarta: Erlangga, 1999.

[9] K. Kartono, Psikologi Umum, Bandung: ALUMNI, 1984.

[10] U. Munandar, Mengembangkan Bakat dan Kreatifitas Anak Sekolah, Jakarta: Gramedia, 1999.

[11] H. Masruroh and I. W. Widayat, "Strategi Orang Tua Dalam Mengembangkan Kreativitas Anak Gifted," Jurnal Psikologi Pendidikan dan Perkembangan, vol. 3, no. 3, 2016.

[12] J.P Guilford, Fundamental Static in Psycology and Education, New York: MC Graw-Hill, 1973.

[13] Rohani, "Meningkatkan Kreativitas Anak Usia Dini Melalui Media Bahan Bekas," Raudhah Program Studi Pendidikan Guru, vol. 5, no. 2, 2017.

[14] M. Syah, Psikologi Pendidikan Dengan Pendekatan Baru . Revisi, Bandung: Rosdakarya, 1977.

[15] M. Yamin and J. S. Sanan, Panduan PAUD (Pendidikan anak Usia Dini), Jakarta : Referensi, 2013.

[16] G. S. Marisson, Dasar Dasar Pendidikan Anak Usia Dini (PAUD). Edisi ke lima, Jakarta Barat: PT Indeks, 2012.

[17] Suyadi, Psikologi Belajar Pendidikan Anak Usia Dini, Yogyakarta: PT Pusaka Insani Madani, 2010.

[18] J. W. Santrock, Life Span Development Terj. Perkembangan Masa Hidup. Edisi 5, Jakarta: Erlangga, 2002.

[19] Y. Jahja, Psikologi Perkembangan, Jakarta: Kencana, 2011.

[20] A. Susanto, Perkembangan Anak Usia Dini (Pengantar Dalam Berbagai Aspeknya), Jakarta: Kencana, 2011.

[21] L. E. Berk, Development Through The Lifespan, Terj, Yogyakarta: Pustaka Pelajar, 2012. 
[22] U. Munandar, Pengembangan Kreativitas Anak Berbakat. Cetakan ke-3, Jakarta: PT Rineka Cipta, 2009.

[23] F. Marilyn, Keperawatan Keluarga: Teori dan Praktik, Jakarta: EGC, 1998.

[24] A. Holis, "Peranan Keluarga /Orang Tua Dan Sekolah Dalam Mengembangkan Kreativitas Anak Usia Dini," Jurnal Pendidikan Universitas Garut, vol. 1, no. 1, 2007.
[25] T. R. Yulianti, "Peranan Orang Tua Dalam Mengembangkan Kreativitas Anak Usia Dini (Studi Kasus Pada Pos PAUD Melati 13 Kelurahan Padasuka Kecamatan Cimahi Tengah)," Jurnal Empowerment, vol. 4, no. 1, 2014. 